\title{
An assessment of software for flow cytometry analysis in banana plants
}

\section{Avaliação de softwares para análises de citometria de fluxo em bananeira}

\author{
Renata Alves Lara Silva ${ }^{1 *}$; Leila Aparecida Salles Pio²; Moacir Pasqual2; \\ Ana Catarina Lima de Oliveira ${ }^{3}$; Filipe Almendagna Rodrigues ${ }^{4}$; \\ Sebastião de Oliveira e Silva ${ }^{5}$
}

\begin{abstract}
Flow cytometry is a technique that yields rapid results in analyses of cell properties such as volume, morphological complexity and quantitative DNA content, and it is considered more convenient than other techniques. However, the analysis usually generates histograms marked by variations that can be produced by many factors, including differences between the software packages that capture the data generated by the flow cytometer. The objective of the present work was to evaluate the performance of four software products commonly used in flow cytometry based on quantifications of DNA content and analyses of the coefficients of variation associated with the software outputs. Readings were obtained from 25 'NBA' (AA) banana leaf samples using the FACSCalibur (BD) flow cytometer, and 25 histograms from each software product (CellQuest ${ }^{\mathrm{TM}}$, WinMDI ${ }^{\mathrm{TM}}$, FlowJo $^{\mathrm{TM}}$ and FCS Express ${ }^{\mathrm{TM}}$ ) were analyzed to obtain the estimated DNA content and the coefficient of variation (CV) of the estimates. The values of DNA content obtained from the software did not differ significantly. However, the CV analysis showed that the precision of the WinMDI ${ }^{\mathrm{TM}}$ software was low and that the $\mathrm{CV}$ values were underestimated, whereas the remaining software showed CV values that were in relatively close agreement with those found in the literature. The CellQuest ${ }^{\mathrm{TM}}$ software is recommended because it was developed by the same company that produces the flow cytometer used in the present study.

Key words: Coefficient of variation, DNA content, CellQuest ${ }^{\mathrm{TM}}$, WinMDI $^{\mathrm{TM}}$, FlowJo ${ }^{\mathrm{TM}}$, FCS Express ${ }^{\mathrm{TM}}$
\end{abstract}

\section{Resumo}

A citometria de fluxo é uma técnica que apresenta resultados com extrema rapidez para análises de propriedades celulares como volume, complexidade morfológica e conteúdo de DNA, e é considerada mais conveniente que outras técnicas. Entretanto, as análises muitas vezes geram histogramas com variações que podem ser devidas a vários fatores, dentre os quais, as diferenças entre os softwares que realizam a aquisição dos dados gerados pelo citômetro de fluxo. Este trabalho foi realizado com o objetivo de avaliar o desempenho de quatro softwares comumente utilizados em análises de citometria de fluxo, por meio de quantificações do conteúdo de DNA e análises do coeficiente de variação gerados por eles. Foram realizadas leituras de 25 amostras foliares de bananeira 'NBA' (AA) utilizando o citômetro de fluxo modelo FACSCalibur (BD) e 25 histogramas de cada software (CellQuest ${ }^{\mathrm{TM}}$, WinMDI $^{\mathrm{TM}}$, FlowJo ${ }^{\mathrm{TM}}$

\footnotetext{
${ }^{1}$ Doctoral Student, Federal University of Lavras, UFLA, Lavras, MG, Brazil. E-mail: renata_vga@yahoo.com.br

${ }^{2}$ Profs. of Federal University of Lavras, UFLA, Lavras, MG, Brazil. E-mail: leilapio.ufla@gmail.com; mpasqual@dag.ufla.br

${ }^{3}$ Prof. of Federal Institute of Sergipe, IFS, Nossa Senhora da Glória, SE, Brazil. E-mail: kata_lima@yahoo.com.br

${ }^{4}$ Post Doctoral Fellow, Federal University of Lavras, UFLA, Lavras, MG, Brazil. E-mail: filipealmendagna@yahoo.com.br

${ }^{5}$ Researcher of Brazilian Agricultural Research Corporation, EMBRAPA, Cruz das Almas, BA, Brazil. E-mail: ssilva@cnpmf. embrapa.br

* Author for correspondence
} 
e FCS Express ${ }^{\mathrm{TM}}$ ) foram analisados para obtenção do conteúdo de DNA estimado e do coeficiente de variação das estimativas. Não há diferença entre os softwares quanto aos valores de conteúdo de DNA. Entretanto, as análises do CV indicaram que a precisão do software WinMDI ${ }^{\mathrm{TM}}$ foi baixa e que os valores de $\mathrm{CV}$ foram subestimados, enquanto que os demais softwares apresentaram valores de $\mathrm{CV}$ mais condizentes com a literatura. O software CellQuest ${ }^{\mathrm{TM}}$ é recomendado por ser desenvolvido pela própria empresa fabricante do citômetro de fluxo utilizado nas análises do presente trabalho.

Palavras-chave: Coeficiente de variação, conteúdo de DNA, CellQuest ${ }^{\mathrm{TM}}$, WinMDI ${ }^{\mathrm{TM}}$, FlowJo $^{\mathrm{TM}}$, FCS Express $^{\mathrm{TM}}$

Flow cytometry is a productive method for studying numerous cellular characteristics. It can be used to analyze a large number of cells individually (LOUREIRO et al., 2007). In recent years, this method has been considered the most rapid and the most convenient of the available techniques (SUDA; TRAVNICEK, 2006). However, the histograms obtained from the method always include variation because the measurement of the DNA content is not perfect (DOLEZEL; GREILHUBER; SUDA, 2007b). This variation, whose sources can range from the methodology used for sample preparation to the cytometer readings and the programs used in the analysis, is expressed by a coefficient of variation $(\mathrm{CV}=$ standard deviation/average), which usually varies from 1 to $10 \%$ for plant cells. According to Marie and Brown (1993), the CV is a basic criterion for the validation of cytological methods and defines a broad spectrum of values ranging from 1 to $2 \%$ for high-quality analysis and 3\% for routine analysis.

Studies that aim to achieve greater precision in conjunction with more appropriate information about the distribution of the DNA content and CVs are currently being conducted. Previous studies have addressed tests of isolation buffers (LOUREIRO et al., 2006); plant tissue and the absence and presence of RNAse (DOLEZEL; GREILHUBER; SUDA, 2007a; LOUREIRO et al., 2007); and fluorochromes (type, time of exposure and quantity) (LOUREIRO et al., 2006). However, information about the actual performance of the computer software most commonly used in these analyses is rare.

The evaluation of the quality and precision of the information generated by flow cytometers and encoded by the applied software should be prioritized so that the analysis offers the greatest possible level of reliability. Cytometers are accompanied by software developed by the equipment manufacturer for cytometry data acquisition, e.g., the BD Biosciences company, which created the CellQuest ${ }^{\mathrm{TM}}$ Pro software, and the Beckman Coulter company, which developed the Expo32 software. However, these programs do not have specific functions allowing the quality of the analysis to be evaluated (LE MEUR et al., 2007). The same limitation applies to software products such as Flow $\mathrm{Jo}^{\mathrm{TM}}$, WinMDI ${ }^{\mathrm{TM}}$ and FCS Express ${ }^{\mathrm{TM}}$, which were developed by companies that do not specialize in the fabrication of flow cytometers but that develop software for use in acquiring data from a variety of types of equipment (BONETTA, 2005; CHI, 2010; LE MEUR et al., 2007).

Therefore, the objective of this work is to evaluate the performance of software commonly used in flow cytometry analysis, obtaining more reliable values for DNA content and the coefficient of variation and drawing inferences about the technical quality of each software product. These analyses will help to improve the analyses performed with flow cytometry techniques.

This study was performed in the Plant Tissue Culture Laboratory in the Department of Agriculture at the Federal University of Lavras, Lavras/MG, Brazil. Twenty-five recently collected 'NBA' banana samples were evaluated. To release the cell nuclei, a scalpel was used to crush leaf fragments weighing approximately 20-30 mg in Petri dishes containing $1 \mathrm{~mL}$ of cold LB01 extraction buffer (DOLEZEL; 
BINAROVÁ; LUCRETTI, 1989). The suspension of nuclei was aspirated using two layers of gauze and filtered with $50 \mu \mathrm{m}$ mesh filters. This suspension was maintained in a receptacle containing chopped ice to preserve the material. The nuclei were then stained with $25 \mu \mathrm{L}$ of propidium iodide, and $5 \mu \mathrm{L}$ of RNase was added to each sample. Five thousand nuclei were analyzed/sample in the FACSCalibur BD flow cytometer, and the histograms were obtained with the CellQuest $^{\mathrm{TM}}$ program supplied with the cytometer.

To estimate the DNA content and the coefficient of variation, all 25 samples were analyzed with four software products (CellQuest ${ }^{\mathrm{TM}}$, WinMDI ${ }^{\mathrm{TM}}$, FlowJo $^{\mathrm{TM}}$ and FCS Express $\left.{ }^{\mathrm{TM}}\right)$. The values of the geometric mean and coefficient of variation were automatically calculated by these programs. Based on the geometric mean $\left(\mathrm{G}_{\text {mean }}\right)$ of the samples and the data on the reference standard (Pisum sativum L.), the DNA content of the samples was estimated using the following equation: DNA of the sample $=\left(\mathrm{G} 1_{\text {sample }} / \mathrm{G} 1_{\text {standard }}\right) \times$ DNA $A_{\text {standard }}$, where $\mathrm{G} 1_{\text {sample }}$ refers to the position of the G1 peak of the sample, G1 $1_{\text {standard }}$ refers to the position of the G1 peak of the reference standard and DNA standard $_{\text {refers to the }}$ quantity of nuclear DNA of the species used as the reference standard (Pisum sativum $=9.09 \mathrm{pg}$ ).
The coefficient of variation describes the width of the G1 peak of the sample; therefore, the thinner the G1 peak, the smaller the coefficient of variation, and the more precise the analysis. Hence, in flow cytometry analysis, it is very important to obtain thin peaks. The measurements should be conducted in the position that best represents the average of the population of the nuclei. This position is approximately the middle of the G1 peak of the sample.

The coefficients of variation $(\mathrm{CVs})$ and DNA content values obtained were evaluated with an analysis of variance and an $\mathrm{F}$ test. If statistically significant, the averages were evaluated with a Tukey test ( $\mathrm{p} \leq 0.05)$ using $\mathrm{R}$ software (R DEVELOPMENT CORE TEAM, 2008).

The nuclear DNA content ranged from 1.77 to $1.87 \mathrm{pg}$. These values do not differ statistically. Therefore, the amount of DNA was the same for all treatments, as shown in Table 1. This result is very important because it shows that this software function yields highly homogeneous results and that any one of the four programs may be used for the analysis of banana samples because the estimates of DNA content will not vary among the software products.

Table 1. Average values of nuclear DNA content (pg) and coefficient of variation (\%) obtained for four software products used in flow cytometry. UFLA, Lavras, MG, 2011.

\begin{tabular}{ccc}
\hline Software & Nuclear DNA content 2C $(\mathbf{p g})^{\mathrm{TM}}$ & $\mathbf{C V} \mathbf{( \% )} \mathbf{~}^{\mathbf{1}}$ \\
\hline CellQuest $^{\mathrm{TM}}$ & $1.77^{\mathrm{ns}}$ & $3.20 \mathrm{~b}$ \\
WinMDI $^{\mathrm{TM}}$ & 1.87 & $0.71 \mathrm{a}$ \\
FlowJo $^{\mathrm{TM}}$ & 1.84 & $4.70 \mathrm{c}$ \\
FCS Express $^{\mathrm{TM}}$ & 1.80 & $5.40 \mathrm{c}$ \\
\hline CV $(\%)$ & 20.5 & 30.0 \\
\hline
\end{tabular}

${ }^{1}$ Averages followed by the same letter in a given column do not differ from each other (Tukey test, $5 \%$ probability).

${ }^{*}$ ns $=$ non-significant.

Source: Elaboration of the authors. 
However, varying levels of precision were found for the coefficient of variation. These levels of precision depended on the software used for the acquisition and reading of the data.

Of the software products evaluated, WinMDI ${ }^{\mathrm{TM}}$ showed the smallest average value for the CV. Initially, this software might appear ideal because this program gave the lowest $\mathrm{CV}$ of any software evaluated. However, users observed that this software underestimates the $\mathrm{CV}$ values, producing an analysis with misleading results. Furthermore, in certain cases, e.g., the analysis of the reference standard, the geometric mean appeared with the value zero, highlighting an error introduced by the program.

CellQuest $^{\mathrm{TM}}$ software is supplied with the BD Biosciences flow cytometer. This software should supply a more precise analysis of the data because it was developed by the manufacturer of the equipment used for the readings. Moreover, it is expensive and only runs on computers with a Macintosh operating system in conjunction with a program security key. The average $\mathrm{CV}$ value obtained by this software is $3.20 \%$. This value is considered acceptable for flow cytometry analysis. Values close to or less than $3 \%$ are considered good, whereas CV values greater than 5\% are not acceptable (DOLEZEL; GREILHUBER; SUDA, 2007b). Note that CVs obtained for in vitro cultures range approximately from 5\% to $10 \%$ (WEBER et al., 2010).

Despite its high acquisition cost, CellQuest ${ }^{\mathrm{TM}}$ is extremely complete and performs many more types of cellular analyses than WinMDI ${ }^{\mathrm{TM}}$ software, which is free but is considered inferior because the tools it offers are those of a software product with only basic functions (CHI, 2010).

The FlowJo ${ }^{\mathrm{TM}}$ and FCS Express ${ }^{\mathrm{TM}}$ software products must also be purchased separately and offer many resources for advanced analysis. They are considered good programs. The CV values obtained from these two programs did not differ significantly. These values were approximately $5 \%$ in each case.
This result is in agreement with that found by Obae and West (2010), who obtained a CV of $4.9 \%$ for an analysis that used FCS Express ${ }^{\mathrm{TM}}$ software to evaluate the nuclear DNA content of Hydrastis canadensis. Similarly, Chung, Weber and Hipp (2011) found average CV values of approximately $4.3 \%$ in an analysis that used Flow $\mathrm{Jo}^{\mathrm{TM}}$ software to evaluate the nuclear DNA content of Carex scoparia var. scoparia (Cyperaceae). A value close to those cited earlier in this paragraph $(\mathrm{CV}=4.35 \%)$ was obtained by Cousin et al. (2009) for a ploidy analysis performed with FlowJo $^{\mathrm{TM}}$ in Brassica napus. Note that the Becton Dickinson cytometer was used in all the works cited, the same equipment used in the present study.

For the Flow $\mathrm{Jo}^{\mathrm{TM}}$ and FCS Express ${ }^{\mathrm{TM}}$ software, the values of the coefficients of variation would be considered to be very high. However, according to Dolezel, Greilhuber and Suda (2007b), these values are still acceptable, especially if the species under study presents a particularity that interferes with the quality of the analysis. Musa acuminata contains a significant amount of phenolic compounds. The presence of these compounds decreases the final quality of the analysis of in vitro plants (CAMOLESI et al., 2007) because these compounds precipitate during the preparation of these samples, making the cytometer readings difficult. In this case, CVs ranging from $3 \%$ to $5 \%$ may be satisfactory. Figure 1 shows the profiles of the histograms generated for each software product.

Dolezel, Greilhuber and Suda (2007b) report that the use of appropriate software to evaluate the quality of the analysis is extremely important. The advantage of using more stringent software is that more care in the preparation of the samples is demanded from the operator. This care is required to ensure that thinner peaks are always obtained, with CVs that do not surpass the $5 \%$ threshold.

The results of this study show that CellQuest ${ }^{\mathrm{TM}}$ software can be recommended for flow cytometry analysis if the cytometer is a FACSCalibur unit or 
another similar device from the BD Biosciences company. This software is recommended because it is already installed in the equipment, has many features to support analyses and does not alter the final results. Moreover, it is recommended for its good precision, as verified by the analysis of the coefficient of variation. The Flow $\mathrm{Jo}^{\mathrm{TM}}$ and FCS Express $^{\mathrm{TM}}$ programs are considered very good. However, the values obtined for the coefficient of variation for both were high. Furthermore, these programs are very expensive. Their acquisition is not advised if users already have the CellQuest ${ }^{\mathrm{TM}}$ program installed in the computer in the cytometer. However, these programs may be needed if large amounts of data are to be analyzed and the number of computers with the Macintosh operating system is limited. The advantage in this case is that these programs can be run in any operating system. Although WinMDI ${ }^{\mathrm{TM}}$ is free and does not alter the measurements of the DNA content of the samples, it is the least reliable.

Due to its good performance, CellQuest ${ }^{\mathrm{TM}}$ software is recommended for users who have computers that are coupled to Becton Dickinson (BD) flow cytometers. The Flow $\mathrm{Jo}^{\mathrm{TM}}$ and FCS Epress $^{\mathrm{TM}}$ software may also be used if the user does not have a Macintosh operating system.

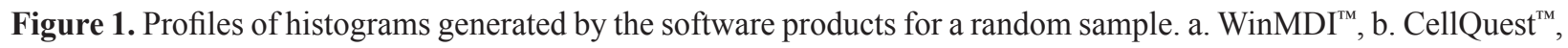
c. FlowJo ${ }^{\mathrm{TM}}$, d. FCS Express ${ }^{\mathrm{TM}}$.

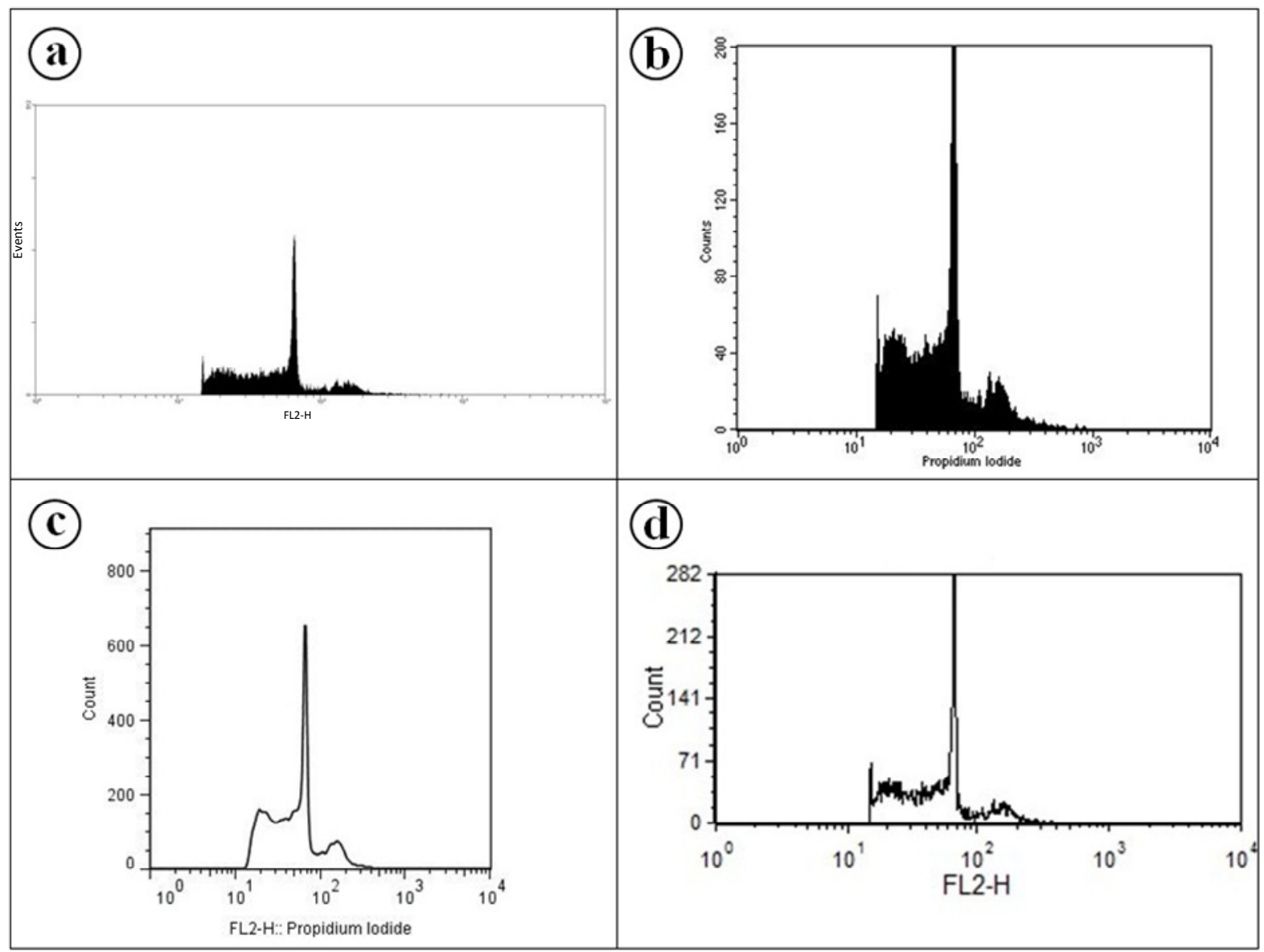

Source: Elaboration of the authors. 


\section{Acknowledgments}

The authors are grateful to Brazilian Federal Agency for the Support and Evaluation of Graduate Education (CAPES) and to the National Council for Scientific and Technological Development (CNPq) for financial support.

\section{References}

BONETTA, L. Flow cytometry smaller and better. Nature Methods, New York, v. 2, n. 10, p. 785-795, oct. 2005.

CAMOLESI, M. R.; KAIHARA, E. S.; SACONI, C. G.; FARIA, R. T.; NEVES, C. S. V. J. Redução da oxidação na propagação in vitro da bananeira 'Maçã'. Ciência \& Agrotecnologia, Lavras, v. 31, n. 4, p. 1237-1241, jul. 2007.

CHI, K. R. Let the data flow: rethink your data analysis tools for flow cytometry. The Scientist, Ontario, v. 24, n. 6, p. 63-64, june 2010.

CHUNG, K. S.; WEBER, J. A.; HIPP, A. L. Dynamics of chromosome number and genome size variation in a cytogenetically variable sedge (Carex scoparia var. scoparia, Cyperaceae). American Journal of Botany, Columbus, v. 98, n. 1, p. 122-129, jan. 2011.

COUSIN, A.; HEEL, K.; COWLING, W. A.; NELSON, M. N. An efficient high-throughput flow cytometry method for estimating DNA ploidy level in plants. Cytometry Part A, Hoboken, v. 75A, n. 12, p. 1015-1019, 2009.

DOLEZEL, J.; BINAROVÁ, P.; LUCRETTI, S. Analysis of nuclear DNA content in plant cells by flow cytometry. Biologia Plantarum, Copenhagen, v. 31, n. 1, p. 113-120, feb. 1989.

DOLEZEL, J.; GREILHUBER, J.; SUDA, J. Estimation of nuclear DNA content in plants using flow cytometry. Nature Protocols, London, v. 2, n. 9, p. 2233-2244, 2007a.
Flow cytometry with plant cells: analysis of genes, chromosomes and genomes. Weinheim: WileyVCH, 2007b. 479 p.

LE MEUR, N.; ROSSINI, A.; GASPARETTO, M.; SMITH, C.; BRINKMAN, R. R.; GENTLEMAN, R. Data quality assessment of ungated flow cytometry data in high throughput experiments. Cytometry Part A, Hoboken, v. 71 A, n. 6, p. 393-403, 2007.

LOUREIRO, J.; RODRIGUEZ, E.; DOLEZEL, J.; SANTOS, C. Comparison of four nuclear isolation buffers for plant DNA flow cytometry. Annals of Botany, London, v. 98, n. 3, p. 679-689, june 2006.

.Two new nuclear isolation buffers for plant DNA flow cytometry: a test with 37 species. Annals of Botany, London, v. 100, n. 4, p. 875-888, oct. 2007.

MARIE, D.; BROWN, S. C. Acytometric exercise in plant DNA histograms, with $2 \mathrm{c}$ values for seventy species. Biology of the Cell, London, v. 78, n. 1, p. 41-51, 1993.

OBAE, S. G.; WEST, T. P. Nuclear DNA content of Hydrastis Canadensis L. and genome size stability of in vitro regenerated plantlets. Plant Cell, Tissue and Organ Culture, Amsterdam, v. 102, n. 2, p. 259-263, aug. 2010.

R DEVELOPMENT CORE TEAM. R: A language and environment for statistical computing. Vienna: $\mathrm{R}$ Foundation for Statistical Computing, 2008. Available at: $<$ http://www.R-project.org>. Accessed at: 15 jan. 2012.

SUDA, J.; TRAVNICEK, P. Reliable DNA ploidy determination in dehydrated tissues of vascular plants by DAPI flow cytometry - new prospects for plant research. Cytometry Part A, Hoboken, v. 69A, n. 4, p. 273-280, 2006.

WEBER, J.; GEORGIEV, V.; HAAS, C.; BLEY, T.; PAVLOV, A. Ploidy levels in Beta vulgaris (red beet) plant organs and in vitro systems. Engineering in Life Sciences, New York, v. 10, n. 2, p. 139-147, feb. 2010. 